\title{
Pendidikan Robbaniyyah dalam Perspektif Al-Qur'an
}

\author{
Otong Surasman \\ Pascasarjana, Institut PTIQ Jakarta, Indonesia \\ otongmomonsurasman@gmail.com
}

\begin{abstract}
Abstrak:
Betapa pentingnya di zaman modern untuk mengembalikan umat manusia ke jalan yang benar, setelah kebanyakan manusia mengambil banyak jalan kehidupan yang tidak benar. Sebagai bukti nyata adalah hilangnya kepribadian manusia yang baik sesuai dengan sifat asal, di mana manusia dilahirkan dalam keadaan suci murni. Lalu betapa pentingnya untuk mengeksplorasi pendidikan rabbaniyyah lagi, sehingga umat manusia masih dapat hidup di dunia ini sesuai dengan sifat kemanusiaan. Sekarang, untuk mencapai semua ini, perlu ada upaya serius dan disiplin, sehingga dengan membangun kembali prinsip-prinsip dasar kehidupan dengan pendidikan rabbanuyah akan terwujud, sehingga dapat menciptakan kehidupan yang penuh keharmonisan, kedamaian, kedamaian dan pemenuhan semua kebutuhan hidup, yang cukup pakaian, makanan dan tempat tinggal, dan bebas dari kemiskinan dan ketidaktahuan dan diskriminasi. Untuk mencapai itu semua membutuhkan solusi yang jelas dan akurat, maka tidak ada upaya lain untuk mengeksplorasi kembali dari sumber asli bimbingan Allah melalui AlQur'an, yang secara khusus mengeksplorasi pendidikan rabbaniyyah dalam Alquran. Dan yang lebih spesifik adalah mengeksplorasi ayat-ayat Al-Qur'an yang terkait erat dengan manusia sebagai an-Nas (makhluk sosial), sehingga setiap manusia akan mengenal dirinya sebagai manusia.
\end{abstract}

Kata Kunci: Pendidikan, Rabbaniyah, Perspektif Al-Qur'an

\begin{abstract}
:
How important it is in modern times to return mankind back to the right path, after most humans have taken many paths of life that are not true. As real proof is the loss of a good human personality according to the nature of origin, where humans are born in a state of pure holiness. Then how important it is to explore rabbaniyyah education again, so that humanity can still be able to live life in this world in accordance with the nature of humanity. Now, to achieve all this, there needs to be serious and disciplined efforts, so that by reestablishing the basic principles of life with rabbanuyah education will be realized, so as to create a life full of harmony, peace, peace and fulfillment of all the needs of life, that is enough clothing, food and shelter, and free from poverty and ignorance and discrimination. To achieve that all of them need clear and accurate solutions, then there is no other effort is to re-explore from the original source of Allah's guidance through the Holy Qur'an, which specifically explores rabbaniyyah education in the Qur'an. And more specific is to explore the verses of the Qur'an that are closely bound to humans as an-Nas (social beings), so that every human being will come to know himself as a human being.
\end{abstract}

Keywords: Education, Rabbaniyah, Perspective of the Qur'an 
Syarah Busyra, Lutfiah Sani

\section{Pendahuluan}

Upaya-upaya mencari sebuah solusi permasalahan kehidupan, yang mengantarkan turunnya kitab suci Al-Qur'an dilakukan oleh sosok pemuda yang gagah berani, jujur, berakhlak mulia (ramah, sopan santun, penyabar). Dari mulai usia kisaran 33 tahun, pemuda ini selalu bertahanus di Gua Hira, yang kemudian dikenal sosok pemuda ini mendapatkan gelar Al-Amin, yang puncaknya mendapatkan titel Nabi dan Rasul terakhir Nabi Muhammad SAW.

Konsep pertama kali, Allah SWT turunkan kepada Rasulullah SAW melalui perantaraan malaikat Jibril AS adalah konsep revolusi membaca, walaupun hanya lima ayat pendek, tetapi mengandung makna yang sangat dahsyat kalau dipahami dengan penuh perenungan terhadap kandungan maknanya. Satu paket konsep yang sangat sempurna, yang telah menjadi bukti kenyataan di zaman sekarang ini, siapa pun yang mengikuti konsep tersebut, apakah dilakukan secara mandiri atau bersama, maka akan mengalami kemajuan yang saangat luar biasa. Walaupun pada kenyataannya, umat Islam saat ini - yang mempunyai konsep, ternyata melupakan konsep tersebut, yang banyak mengambil adalah orang-orang non Islam.

Mengapa hal ini terjadi? Jawaban sederhana, karena umat Islam tidak gemar membaca, meneliti, mendalami kandungan ayat-ayat Allah SWT, baik terkandung dalam kitab suci AlQur'an, maupun yang terhampar dijagad raya ini sebagai ayat kauniyah. Bukti yang sederhana saat ini adalah $70 \%$ umat Islam buta huruf Al-Qur'an, $20 \%$ terbata-bata dan hanya $10 \%$ yang mampu membaca Al-Qur'an. Kemudian yang $10 \%$ terbagi lagi, pertama mampu membaca AlQur'an secara baik dan benar, tetapi tidak mempunyai sanad bacaan Al-Qur'an yang resmi, juga tidak memahami isi kandungan Al-Qur'an dengan baik dan benar. Kedua, mampu membaca Al-Qur'an secara baik dan benar, mempunyai sanad bacaan Al-Qur'an yang resmi, akan tetapi tidak memamahi kandungan Al-Qur'an dengan baik dan benar. Ketiga, mampu membaca Al-Qur'an secara baik dan benar, mempunyai sanad bacaan Al-Qur'an yang resmi, memahami sebagian kandungan Al-Qur'an, akan tetapi belum mampu mengamalkannya dalam kehidupan nyata. Keempat, mampu membaca Al-Qur'an secara baik dan benar, mempunyai sanad bacaan Al-Qur'an yang resmi, mengetahui sebagian besar kandungan Al-Qur'an dan berusaha mengamalkan kandungannya dalam kehidupan sehari-hari.

Inilah gambaran umum kondisi umat Islam saat ini, yang menjadi dasar pemikiran penulis untuk menulis sebuah jurnal dengan judul "Pendidikan Rabbaniyyah Dalam Perspektif Al-Qur'an”, sebuah upaya mengembalikan umat Islam kepada konsep dasar yang dahsyat, yaitu revolusi membaca, membaca Al-Qur' an mencapai yatluuna Kitaballah. 


\section{Prinsip dasar pendidikan rabbaniyyah}

Prisip dasar pendidikan rabbaniyyah secara mendalam dan lengkap dimulai oleh Abu Al-Anbiya' Nabi Ibrahim AS. Maka sebagai pijakan awal perlu mengetahui tentang sejarah Nabi Ibrahim AS, di mana dalam sebuah literatur Nabi Ibrâhîm as dikisahkan bahwa beliau adalah putra Ăzar bin Nahur bin Saruj bin Ra'u bin Falij bin Abir bin Syalih bin Arfakhsyadz bin Syam bin Nûh as. Diperkirakan periode sejarah beliau 1997-1822 SM dan diutus untuk menyampaikan dakwah kepada ayah dan kaumnya, yaitu Bangsa Kaldan sekitar 1900 SM di Ur daerah Irak. Nama Nabi Ibrâhîm as disebut dalam Al-Qur'ân sebanyak 69 kali dan tempat wafat beliau di al-Khalîl Hebron. ${ }^{1}$ Nabi Ibrâhîm as mempunyai badan yang tinggi ${ }^{2}$ dan wajahnya mirip dengan Nabi Muhammad saw. ${ }^{3}$

Nabi Ibrâhîm al-Khalîl dilahirkan di Ur, daerah bagian selatan Irak. Beliau lahir di kalangan masyarakat penyembah berhala. Mereka membuat patung pada zaman Raja Namrud bin Kan'an. Ayahnya, Ăzar adalah seorang yang cukup pandai dalam membuat berhala yang menyesatkan itu. Dia lalu memerintahkan Ibrâhîm untuk menjualnya ke pasar. Ibrâhîm pun membawanya dan berteriak di pasar, "Siapa yang mau membeli benda berbahaya dan tidak bermanfaat ini?"

Menurut versi lain ditemukan data tentang Nabi Ibrâhîm as sebagai berikut: Nabi Ibrâhîm as di lahirkan di Ur Irak pada tahun 2166 SM, ayahnya Ăzar. Pada usia 14 tahun (2152 SM) Nabi Ibrâhîm as mulai mengamati alam untuk sampai pada keyakinan monoteisme dan mulai menyampaikan pesan ini kepada masyarakat Ur. Pada usia 16 tahun (2150 SM) Nabi

\footnotetext{
${ }^{1}$ Sami bin Abdullah al-Maghlouth, Atlas Sejarah para Nabi dan Rasul, penerjemah: Qasim Saleh, dkk, (Jakarta: Almahira, 2012), cet. 4, hal. 45.

${ }^{2}$ Nabi Ibrâhîm as mempunyai badan yang tinggi, hal ini dijelaskan pada hadis yang diriwayatkan oleh al-Bukhari, melalui jalur riwayat Samurah bin Jundub ra, ia berkata: Rasulullah saw pernah bersabda, "Pada suatu malam aku bermimpi didatangi oleh dua orang, kemudian mereka mengajakku pergi dan bertemu dengan seorang laki-laki yang tinggi yang hampir tidak bisa aku lihat wajahnya karena amat tingginya, dia adalah Ibrâhîm." Abî Abdillah Muhammad bin Ismâîl al-Bukharî, Shahîh al-Bukharî, (Mesir: Dâr al-Afâq al'Arabiyyah, 2004), cet. 1, juz. 2, nomor hadis. 3354, hal. 765. Redaksi lengkapnya pada lampiran hadis.

${ }^{3}$ Nabi Ibrâhîm as wajahnya mirip dengan Nabi Muhammad saw, hal ini dijelaskan pada hadis yang diriwayatkan oleh al-Bukhari, melalui jalur Abdullah bin Abbas ra, dia berkata: Rasulullah saw pernah bersabda, "Jika kalian ingin tahu seperti apa Ibrâhîm, lihatlah sahabat kalian (yaitu Nabi Muhammad saw), adapun Mûsâ as adalah berambut keriting, berkulit coklat, menunggang onta merah, tali kekangnya terbuat dari pelepah kurma, seolah aku melihatnya menuruni lembah." Abî Abdillah Muhammad bin Ismâîl al-Bukharî, Shahîh alBukharî, (Mesir: Dâr al-Afâq al-'Arabiyyah, 2004), cet. 1, juz. 2, nomor hadis. 3355, hal. 765. Redaksi lengkapnya pada lampiran hadis.
} hal. 94.

${ }^{4}$ Sami bin Abdullah al-Maghlouth, Atlas Sejarah para Nabi dan Rasul, penerjemah: Qasim Saleh, dkk, 
Ibrâhîm as menghancurkan berhala dan diadili oleh kaisar Naram Sin, serta dilemparkan ke dalam api. ${ }^{5}$

Ketika beranjak dewasa, beliau mengingkari perlakuan kaumnya yang menyembah berhala. Dalam benaknya, terlintas beragam pertanyaan dan penalaran tentang kaumnya. Mereka hidup dalam kelalaian dan kesesatan karena keyakinan yang rusak terhadap berhala, patung, dan bintang. Setelah Nabi Ibrâhîm as bersenjatakan kebenaran dan logika ketika Allah swt menjadikan beberapa sebab itu untuknya, pertengkaran pun terjadi antara Nabi Ibrâhîm as dan orang-orang kafir serta orang-orang yang sesat. Beliau pun mengingatkan ayahnya dengan sangat bijaksana dan penuh nasehat. Akan tetapi, sang ayah bersikeras dalam kesesatan dan kebodohan. Nabi Ibrâhîm as tetap mengajak kaumnya untuk beribadah kepada Allah swt semata dan mengahancurkan berhala. ${ }^{6}$

Berita tentang prilaku beliau menghancurkan berhala, lalu tersebar ke seluruh penduduk Babylon hingga Raja Namrud mengajak berdebat. Mereka berdua pun bertemu. Nabi Ibrâhîm as melancarkan berbagai argumen dan dalil-dalil sehingga dapat mematahkan lawannya. Pada suatu hari, Nabi Ibrâhîm as menghancurkan berhala-berhala yang ada dan meninggalkan salah satunya (yang paling besar) karena ada tujuan tertentu. Ketika orang-orang berdatangan ke tempat tersebut, mereka menemukan semuanya hancur dan berantakan. Mereka pun marah, dendam, dan berjanji akan memberikan hukuman yang sangat berat kepada orang yang telah melakukannya. Setelah berusaha mencari pelakunya, mereka mengetahui bahwa Nabi Ibrâhîm as bin Ăzar yang melakukannya. Setelah itu, mereka pun menyidangnya, dan setelah mengalami kebuntuan yang paling buruk karena tidak mampu melawan argumen Nabi Ibrâhîm as, maka diputuskan untuk membakar Nabi Ibrâhîm as. ${ }^{7}$

Setelah jelas posisi yang dialami antara Nabi Ibrâhîm as dengan ayahnya dan kaumnya yang jelas-jelas mereka menginginkan untuk membakar Nabi Ibrâhîm as dan mengharapkan kebinasaannya, dan Allah swt menginginkan untuk merendahkan mereka serendah-rendahnya, maka Allah swt menyelamatkan Nabi Ibrâhîm as dari seluruh kebusukan hati mereka. Ketika itulah Nabi Ibrahim as, menetapkan untuk berhijrah menuju tempat yang diperintahkan oleh Allah swt. Beliau hijrah hanya ditemani keponakannya Lûth bin Hârûn dan istrinya Sarah serta

5 Jeradl F Dirks, Ibrahim Sang Sahabat Tuhan, penerjemah: Satrio Wahono, (Jakarta: PT Serambi Ilmu Semesta, 2006), cet. 2, hal. 286.

${ }^{6}$ Sami bin Abdullah al-Maghlouth, Atlas Sejarah para Nabi dan Rasul, penerjemah: Qasim Saleh, dkk, hal. 94. hal. 94. 
saudara laki-lakinya yang Allah swt berikan kepadanya keturunan yang saleh. Beliau berhijrah menuju negeri Syam dan negeri yang disucikan (Palestina). ${ }^{8}$

Kemudian Nabi Ibrâhîm as hijrah ke Mesir, hal itu diawali ketika Nabi Ibrâhîm as sampai di Syam, ia sangat leluasa untuk melakukan apa pun juga. Namun kemudian ia pergi ke Yaman. Saat itu di Syam sedang musim paceklik, harga-harga mahal, serta kondisi sangat gersang. Biaya hidup sangat tinggi sehingga sulit sekali untuk menjalani kehidupan di sana. Kemudian Nabi Ibrâhîm as pergi menuju Mesir didampingi istrinya Sarah. Ia memasuki Mesir, kemudian menetap di sana dengan leluasa. Ia seorang yang tenang jiwanya, santun akhlaknya, sopan prilakunya, dermawan, dan senang bekerja keras. Oleh sebab itu, ia memiliki harta yang banyak, kenikmatan yang berlimpah, dan dikenal oleh masyarakat. ${ }^{9}$

Selama Nabi Ibrâhîm as tinggal di Mesir, ada empat kejadian penting yang dilaporkan. Kejadian pertama adalah Nabi Ibrâhîm as dan Lûth menjadi kaya serta makmur selama berada di Mesir. Kedua, Lûth menikah dengan seorang perempuan Mesir. Ketiga, Nabi Ibrâhîm as meneruskan misi dakwahnya selama tinggal di sana. Keempat, Sarah dibawa ke istana Firaun. Jubilee (Yobel) menyatakan bahwa peristiwa ini terjadi setelah Nabi Ibrâhîm as tinggal di Mesir selama lima tahun. ${ }^{10}$ Kronologis peristiwa tersebut terjadi sebagai berikut: "Nabi Ibrâhîm as, Sarah, dan Lûth sampai di Mesir ketika terjadi kelaparan besar-besaran. Selama lima tahun tinggal di Mesir, Nabi Ibrâhîm as, dan Lûth menjadi kaya serta makmur. Kemudian Lûth menikah dengan seorang perempuan Mesir. Nabi Ibrâhîm as terus menyiarkan dakwah selama di Mesir. Firaun mengambil Sarah dari Nabi Ibrâhîm as karena mengira bahwa Sarah adalah saudara perempuan Nabi Ibrâhîm as dan bukan istrinya. Firaun merasa menderita ketika ia mendekati Sarah. Firaun mengembalikan Sarah dan memberi hadiah kepada Nabi Ibrâhîm as dan Sarah, termasuk memberikan seorang pelayan bernama Hajar. Firaun memerintahkan Nabi Ibrâhîm as, Sarah, dan Lûth meninggalkan Mesir. ${ }^{11}$

Setelah Nabi Ibrâhîm as tinggal sekian lama di Mesir, ia kembali untuk kedua kalinya menuju Palestina. Ia membawa bekal harta yang cukup banyak dan rezeki yang cukup memadai. Ia tinggal di Palestina bersama sekelompok kecil orang-orang yang beriman kepadanya dan menyambut seruan dakwahnya. Ia juga didampingi oleh istrinya Sarah dan

\footnotetext{
${ }^{8}$ Ahzami Samiun Jazuli, Hijrah dalam Pandangan Al-Qur'ân, penerjemah: Eko Yulianti, (Jakarta: Gema Insani, 2006), cet. 1, hal. 125.

${ }^{9}$ Ahzami Samiun Jazuli, Hijrah dalam Pandangan Al-Qur'ân, penerjemah: Eko Yulianti, (Jakarta: Gema Insani, 2006), cet. 1, hal. 126.

${ }^{10}$ Jeradl F Dirks, Ibrahim Sang Sahabat Tuhan, penerjemah: Satrio Wahono, hal. 262.

11 Jeradl F Dirks, Ibrahim Sang Sahabat Tuhan, penerjemah: Satrio Wahono, hal. 264.
} 
budak perempuannya dari Mesir, yaitu Hajar. Saat itu Nabi Ibrâhîm as masih menyempurnakan dakwahnya dan menyampaikan risalah Allah swt. ${ }^{12}$

Dengan berhijrah meninggalkan Mesir, ternyata berdampak psikilogi sangat besar bagi Nabi Ibrâhîm as. Ia mendapat hikmah dan pelajaran dari perjalanannya itu baik berupa cobaancobaan, bergaul dengan berbagai manusia, ujian-ujian yang menakutkan, serta berbagai rintangan dan tantangan yang harus dihadapi Nabi Ibrâhîm as. Namun demikianlah sunnatullah yang diberikan kepada para nabi bahkan seluruh nabi yang terpilih hingga begitu jiwa mereka menjadi bersih karena tempaan alam dan bergulirnya waktu serta tempaan cobaan agar mereka menjadi teladan terbaik, contoh termulia bagi setiap masa dan generasi. ${ }^{13}$

Kemudian Nabi Ibrâhîm as berhijrah menuju Mekah bersama anaknya Ismail yang masih menyusui dan istrinya Hajar. Saat itu, di Mekah tidak ada seorang pun dan tidak ada setetes air pun. Nabi Ibrâhîm as meninggalkan mereka berdua di sana dan ia menyimpan sebuah tas berisi kurma dan sebuah tempat air yang berisi air. Nabi Ibrâhîm as kembali menuju Syam tanpa mengajak dan menghiraukan anak istrinya. Setelah selang beberapa tahun kemudian Nabi Ibrâhîm as kembali ke Mekah untuk melaksanakan perintah Allah swt, bersama Ismail membangun Ka'bah. Kemudian Nabi Ibrâhîm as kembali untuk kedua kalinya dari Hijaz menuju Palestina. Ketika maut menjemputnya, ia dalam usia dua ratus tahun. Ada yang mengatakan seratus lima puluh tahun atau seratus tujuh puluh tahun. Ia di kuburkan di samping kuburan Sarah di perkebunan Hebron. ${ }^{14}$

Sebagai landasan dasar pendidikan rabbaniyyah terekam dalam kitab suci Al-Qur'an do'a Nabi yang suci bapaknya para nabi, terurai dengan indahnya pada Al-Qur'an surah AlBaqarah/2 mulai ayat 126 sampai 129.

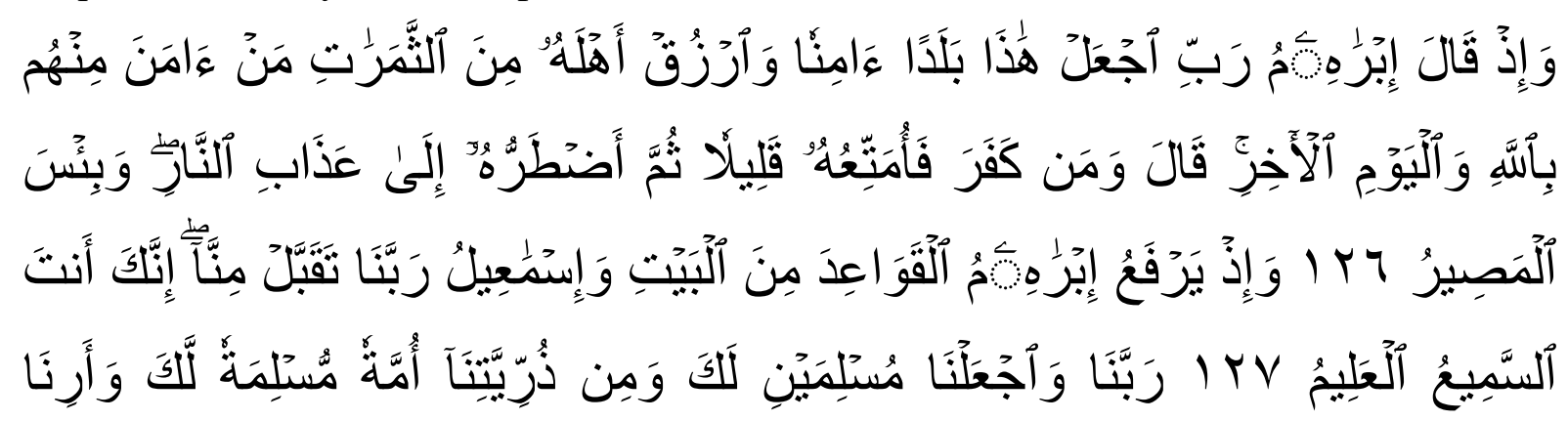

${ }^{12}$ Ahzami Samiun Jazuli, Al-Hijrah fî Al-Qur'ân, Hijrah dalam Pandangan Al-Qur'ân, penerjemah: Eko Yulianti, hal. 130.

${ }^{13}$ Ahzami Samiun Jazuli, Al-Hijrah fì Al-Qur'ân, Hijrah dalam Pandangan Al-Qur'ân, penerjemah: Eko Yulianti, hal. 130.

${ }^{14}$ Ahzami Samiun Jazuli, Al-Hijrah fî̀ Al-Qur'ân, Hijrah dalam Pandangan Al-Qur'ân, penerjemah: Eko Yulianti, hal. 134. Lihat pula: Abû Ja'far Muhammad bin Jarîr ath-Thabarî, Tarîkh al-Umam wa al-Mulûk, (Beirut: Dâr al-Fikr, TT), Jilid. 1, hal. 296. 


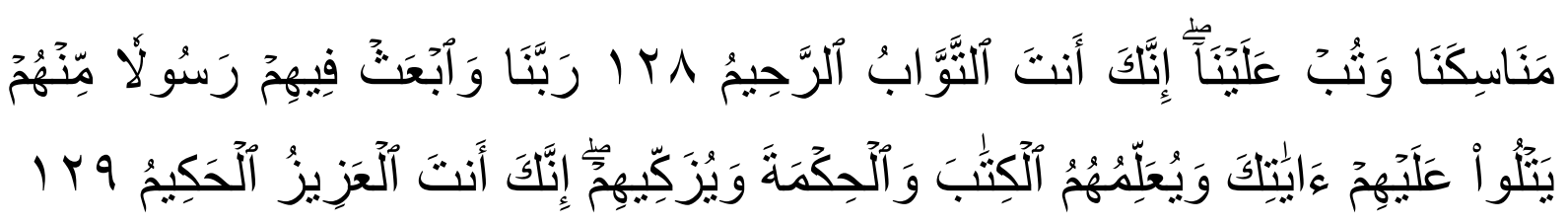

Dan (ingatlah), ketika Ibrahim berdoa: "Ya Tuhanku, jadikanlah negeri ini, negeri yang aman sentosa, dan berikanlah rezeki dari buah-buahan kepada penduduknya yang beriman diantara mereka kepada Allah dan hari kemudian. Allah berfirman: "Dan kepada orang yang kafirpun Aku beri kesenangan sementara, kemudian Aku paksa ia menjalani siksa neraka dan itulah seburuk-buruk tempat kembali". Dan (ingatlah), ketika Ibrahim meninggikan (membina) dasardasar Baitullah bersama Ismail (seraya berdoa): "Ya Tuhan kami terimalah daripada kami (amalan kami), sesungguhnya Engkaulah Yang Maha Mendengar lagi Maha Mengetahui". Ya Tuhan kami, jadikanlah kami berdua orang yang tunduk patuh kepada Engkau dan (jadikanlah) diantara anak cucu kami umat yang tunduk patuh kepada Engkau dan tunjukkanlah kepada kami cara-cara dan tempat-tempat ibadat haji kami, dan terimalah taubat kami. Sesungguhnya Engkaulah Yang Maha Penerima taubat lagi Maha Penyayang. Ya Tuhan kami, utuslah untuk mereka sesorang Rasul dari kalangan mereka, yang akan membacakan kepada mereka ayatayat Engkau, dan mengajarkan kepada mereka Al-Kitab (Al Qur'an) dan Al-Hikmah (AsSunnah) serta mensucikan mereka. Sesungguhnya Engkaulah yang Maha Kuasa lagi Maha Bijaksana.

Pada ayat 126 surah Al-Baqarah prinsip dasar pendidikan rabbaniyyah adalah bagaimana agar terciptanya suatu negara atau masyarakat yang aman sentosa, damai, tentram dan penuh dengan kesejahteraan, terhindar dari kemiskinan dan kebodohan.

Dalam ayat di atas, Nabi Ibrâhîm as memohon kepada Allah swt, dua hal penting demi kebaikan penduduk tanah suci, pada ayat 126 yaitu: "Dan (ingatlah) ketika Ibrâhîm berdoa, 'Ya Tuhanku, jadikanlah negeri ini, negeri yang aman sentosa, dan berikanlah rezeki dari buahbuahan kepada penduduknya yang beriman di antara mereka kepada Allah swt dan hari kemudian". Allah swt mengabulkan doa Nabi Ibrâhîm as dan menjadikan tanah suci ini sebagai pusat keamanan baik lahir dan batin. Dan yang patut dicermati di sini bahwa Nabi Ibrâhîm as memohon "keamanan" dahulu, baru beliau memohon karunia materi yang terwujud apabila status ekonomi yang baik dan keamanan di kota atau di desa terjamin." 15

Patut pula diperhatikan bahwa doa Nabi Ibrâhîm as, membatasi doa ini hanya untuk orang-orang yang beriman kepada Allah swt dan pada hari akhirat, karena boleh jadi

\footnotetext{
${ }^{15}$ Kamal Faqih dan Tim Ulama, Tafsîr Nurul Qur'ân, penerjemah: R Hikmat Danaatmaja, (Jakarta, Penerbit Al-Hudâ, 2003), cet. 1, hal. 343-344.
} 
memahami ungkapan ini, "Janjiku tidak akan mengenai orang-orang yang zalim," yang disebutkan dalam ayat sebelumnya, menunjukkan dirinya tahu bahwa sesungguhnya sebagian keturunannya di masa depan akan meneratas jalan kemusyrikan dan kezaliman, maka dari itu, untuk memperlihatkan ketundukan dalam suatu cara santun di sini, ia tidak memasukkan orangorang tersebut dalam doanya. Namun demikian, sesungguhnya rahmat Allah swt yang umum diperuntukkan bagi segenap makhluk Allah swt, sehingga orang-orang yang beramal baik dan buruk akan menikmati karunia dunia yang luas secara adil. Namun di dunia yang akan datang, di akhirat nanti, orang-orang yang beramal buruk, bukan saja tidak akan mendapat bagian bahkan mereka tidak akan mendapat jalan untuk menyelamatkan diri mereka sendiri. ${ }^{16}$

Doa Nabi Ibrâhîm as untuk menjadikan kota Mekah dan sekitarnya sebagai kota yang aman adalah doa untuk menjadikan keamanan yang ada di sana berkesinambungan hingga akhir masa, atau menganugerahkan kepada penduduk dan pengunjungnya kemampuan untuk menjadikannya aman dan tentram. Doa Nabi Ibrâhîm as tersebut adalah: “Tuhanku, jadikanlah negeri ini yang aman sentosa, dan berikanlah rezeki berupa buah-buahan kepada penduduknya yang beriman di antara mereka kepada Allah dan hari kemudian." Ayat ini bukan saja mengajarkan agar berdoa untuk keamanan dan kesejahteraan kota Mekah, tetapi juga mengandung isyarat tentang perlunya setiap muslim berdoa untuk keselamatan dan keamanan wilayah tempat tinggalnya dan agar penduduknya memperoleh rezeki yang melimpah."17

Mengenai penafsiran sûrah Al-Baqarah/2 ayat 127, dapat dipahami dengan jelas dari berbagai ayat Al-Qur'ân, hadits, dan beberapa catatan sejarah bahwa Baitullah didirikan sebelum Nabi Ibrâhîm as. Bangunan ini telah didirikan sejak Nabi Ădam as, hal ini sebagaimana dijelaskan pada sûrah Ibrâhîm/14 ayat 37 mengutip dari lisan Nabi Ibrâhîm as yang mengatakan, "Ya Tuhan kami! Sesungguhnya aku telah menempatkan sebagian keturunanku di sebuah lembah yang tidak menghasilkan (buah) dekat Rumah Suci (Baitullah)..." Ayat ini menjelaskan bahwa ketika Nabi Ibrâhîm as dan istrinya Hajar serta bayi lelakinya, Nabi Ismâ'îl as , tiba di tanah suci Makkah, tidak ada tanda Ka'bah terlihat di sana, tetapi dia dibimbing ke sana oleh wahyu. Singkat ceritanya, ayat-ayat Al-Qur'ân dan riwayat Islam menegaskan bahwa fakta sejarah ini, menyangkut Baitullah yang pada awalnya dibangun oleh Nabi Ădam as. Kemudian rubuh pada zaman Nabi Nûh as. Akhirnya dibangun kembali melalui tangan Nabi Ibrâhîm as dan Nabi Ismâ'îl as. ${ }^{18}$

\footnotetext{
${ }^{16}$ Kamal Faqih dan Tim Ulama, Tafsîr Nurul Qur'ân, penerjemah: R Hikmat Danaatmaja, hal. 344.

${ }^{17}$ Muhammad Quraish Shihab, Tafsîr al-Mishbah, hal. 306.

${ }^{18}$ Kamal Faqih dan Tim Ulama, Tafsîr Nurul Qur'ân, penerjemah: R Hikmat Danaatmaja, hal. 346-347.
} 
Rangkaian doa pada ayat berikutnya ada lima permohonan penting yang dipanjatkan Nabi Ibrâhîm as dan Nabi Ismâ'îl as. Doa yang dipanjatkan pada saat mereka sibuk membangun bangunan Ka'bah ini, benar-benar tepat dan konsisten dengan segenap kepentingan material dan spiritual, sehingga dapat menyadarkan akan keagungan jiwa dua rasul nan agung ini. Lima doa tersebut adalah: Pertama, "Ya Tuhan kami, jadikanlah kami berdua orang yang tunduk patuh (Muslim) kepada-Mu. Kedua, dan di antara anak cucu kami umat (sebuah bangsa) yang tunduk patuh kepada-Mu. Ketiga, dan tunjukkanlah kepada kami cara-cara beribadah, (sehingga kami dapat menyembah-Mu sesuai dengan kemahatinggian$\mathrm{Mu}$ ). Keempat, dan terimalah tobat kami (dengan penuh rahmat); karena sesungguhnya Engkau Maha Penerima tobat lagi Maha Penyayang. Kelima, ya Tuhan kami, utuslah kepada mereka seorang rasul dari kalangan mereka, yang akan membacakan kepada mereka ayat-ayat-Mu, mengajarkan kepada mereka Al-Kitâb dan Hikmah, dan menyucikan mereka, karena sesungguhnya Engkau Maha Perkasa lagi Maha Bijaksana.”19

Nabi Ibrâhîm as dan Nabi Ismâ'̂̂l as ditugaskan Allah swt untuk meninggikan bangunan Ka'bah, dan setelah selesai, jadilah ia bangunan yang tinggi sehingga terlihat dari segala penjuru. Kedua insan pilihan itu membangun Ka'bah, menyusun batu demi batu sampai sempurna bangunan berbentuk kubus. Mereka tidak menerima upah dari siapapun, mereka hanya bermohon agar amal mereka diterima Allah swt sebagai pengabdian: "Tuhan kami, terimalah dari kami amal kami, sesungguhnya Engkau Maha Mendengar permohonan kami dan Maha Mengetahui kerja, niat, dan tujuan kami."20

Ceritakan wahai Nabi Muhammad saw, kepada kaummu tatkala Nabi Ibrâhîm as dan putranya, Nabi Ismâ'îl as, membangun pondasi Ka'bah. Keutamaannya terletak pada status kedua pembangun ini sebagai nabi, di samping dipilihnya Ka'bah ini sebagai tempat beribadah di tengah negeri penyembah berhala. Keutamaan Ka'bah bukan pada batunya, letak geografisnya, atau bahwa ia turun dari langit. Menghadap ke arahnya dianggap sama dengan menghadap Allah swt. Yang tidak dibatasi oleh tempat maupun arah tertentu. Mengusap Hajar Aswad dihitung sebagai ibadah, sama seperti menghadap ke Ka’bah dalam shalat. Tidak ada keistimewaan pada dzat Hajar aswad itu sendiri. Ia sama dengan batu-batu lain. Dalilnya adalah ucapan Umar bin al-Khaththab ketika mengusapnya: "Demi Allah, aku tahu bahwa engkau hanyalah batu yang tak dapat mendatangkan mudarat maupun manfaat. Seandainya aku tidak

\footnotetext{
${ }^{19}$ Kamal Faqih dan Tim Ulama, Tafsîr Nurul Qur'ân, penerjemah: R Hikmat Danaatmaja, hal. 347.

${ }^{20}$ Muhammad Quraish Shihab, Tafsîr al-Mishbah, hal. 308.
} 
melihat Rasulullah saw menciummu, tentu aku tidak akan menciummu." Kemudian ia pun mendekat lantas menciumnya." 21

Pada saat mendirikan bangunan ini, Nabi Ibrâhîm as dan Nabi Ismâ'̂̂l as berdoa: "Wahai Tuhan kami, sesungguhnya Engkau Maha Mendengar doa kami, Maha Mengetahui niat kami dalam semua amal kami. Wahai Tuhan kami, jadikanlah kami orang yang tunduk kepada-Mu, orang yang murni dalam keyakinan sehingga kami tidak menyembah kecuali kepada-Mu dan tidak meminta pertolongan kecuali kepada-Mu, serta orang yang ikhlas dalam amal sehingga semua amal itu kami niatkan semata-mata demi meraih ridha-Mu. Wahai Tuhan kami, jadikanlah sebagian dari keturunan kami ikhlas kepada-Mu dan tunduk kepada perintahperintah-Mu, agar Islam terus langgeng dalam semua generasi. Wahai Tuhan kami, beritahulah kami tentang urusan ibadah kami dan tempat-tempat ibadah haji kami seperti miqat ihram, tempat wuquf di Arafah, dan tempat thawaf dan sa'i-serta terimalah tobat kami, sesungguhnya Engkaulah Yang Maha Penerima tobat dari hamba-hamba-Mu dan Maha Penyayang terhadap orang-orang yang bertobat untuk menyelematkan mereka dari adzab."22

Allah swt berfiman kepada Nabi Muhammad saw, tentang peristiwa bersejarah yang dilakukan Nabi Ibrâhîm as, saat mengangkat dasar-dasar Baitullah dan (ingatlah) ketika Nabi Ibrâhîm as meninggikan dasar-dasar Baitullah. Kata yarfa'u mengangkat bentuknya fi'il mudhari' yang menunjukkan penggambaran suasana yang terus menerus dari sekarang sampai masa depan. Timbul pertanyaan, apakah Nabi Ibrâhîm as masih mengangkat dasar-dasar tersebut sekarang? Ataukah dia hanya mengangkat dan sesudah itu selesai? Jawabnya: Dia sudah mengangkat dan selesai. Tetapi mengapa Allah swt menggunakan fi'il mudhari' (present continius tense)? Jawabnya: Ia menghendaki peristiwa pengangkatan tersebut berkesinambungan dalam pikiran mukminin. ${ }^{23}$

Dalam proses pembangunan bait ini, Nabi Ibrâhîm as sama sekali tidak mempunyai tangga dan fasilitas lainnya, tetapi hal itu tidak mengurungkan niatnya. Dia berinisiatif dengan sebongkah batu sebagai pengganti tangga. Nabi Ibrâhîm as dan anaknya Nabi Ismâ'îl as mencari batu yang ringan agar dapat dibawa ke lokasi pendirian bangunan. Kemudian Nabi Ibrâhîm as naik ke atas batu dan Nabi Ismâ'îl as membantu memberikan materi bangunan yang lainnya. Meskipun berat kesulitan yang dihadapi, keduanya merasa bahagia dengan tugas tersebut. Karena yang diharapkan oleh mereka berdua hanyalah ridha Allah swt dan ganjaran pahala. Kemudian Nabi Ibrâhîm as dan Nabi Ismâ'îl as berdoa: "Ya Tuhan kami, terimalah

\footnotetext{
${ }^{21}$ Wahbah Mushthafâ az-Zuhaili, At-Tafsîr al-Munîr, jilid. 1, hal. 339-340.

${ }^{22}$ Wahbah Mushthafâ az-Zuhaili, At-Tafsîr al-Munîr, jilid. 1, hal. 339-340.

${ }^{23}$ Muhammad Mutawalli asy-Sya'rawi, Tafsîr asy-Sya'rawi, jilid. 1, hal. 585.
} 
daripada kami (amalan), agar Engkau memberikan pahala terhadap apa yang kami perbuat, karena tugas ini kami laksanakan semata-mata mengharap ridha-Mu. Sesungguhnya Engkau Tuhan Yang Maha Mendengar, yang mendengar doa kami dan mendengar segala ucapan kami, Engkau Tuhan Yang Maha Mengetahui dengan niat kami dan kadar keikhlasan kami. Kami melaksanakan ini, semua hanyalah untuk mencari keridhaan-Mu semata, bukan yang lain, karena amal sangat tergantung kepada niat. Terkadang dua orang beramal dengan pekerjaan yang sama, seorang dari mereka mendapat pahala dan yang lainnya tidak, karena yang kedua mengerjakannya hanyalah untuk kepentingan duniawi semata-mata. Allah swt mengetahui niat seseorang, jika tidak ikhlas, Dia tidak akan menerimanya. ${ }^{24}$

Ada perbedaan antara pelaksanaan taklif dengan terpaksa dan dilaksanakan dengan senang hati. Ayat 128 sûrah Al-Baqarah ini, merupakan bukti bahwa Nabi Ibrâhîm as ridha dan suka melaksanakan tugas mulia itu. Hal ini terbukti lewat doa Nabi Ibrâhîm as dan putranya, Nabi Ismâ'̂̂l as. Mereka berdoa: "Ya Rabb Engkau telah memerintahkan kami mengangkat dasar-dasar Baitullah dan telah kami kerjakan apa yang Kau perintahkan, bukan maksudnya kami hanya merasa cukup dengan beban yang Engkau berikan, karena kami masih ingin menikmati taklif dari-Mu terus menerus. Ya Tuhan kami, jadikanlah kami berdua orang yang tunduk patuh kepada Engkau, kami serahkan urusan kami hanya kepada-Mu.” Manusia tidak akan berhenti menuntut taklif yang baru, jika telah dapat menikmati manisnya taklif itu, dan tidak akan dapat menikmatinya, kecuali telah tergambar padanya balasan pahala yang dijanjikan kepadanya. ${ }^{25}$

Dengan selesai membangun dasar-dasar bait, Nabi Ibrâhîm as dan Nabi Ismâ'îl as berdoa: "Ya Tuhan kami, jadikanlah kami berdua orang yang tunduk patuh kepada Engkau. Keduanya tidak merasa beban dengan hal tersebut, tetapi mereka bermaksud pula memberikan manisnya taklif kepada anak cucunya di belakang hari nanti. Mereka pun meneruskan doanya: "Dan (jadikanlah) di antara anak cucu kami umat yang tunduk dan patuh kepada-Mu. Maksudnya agar ada kesinambungan pilar manhaj Allah swt di muka bumi. Agar taklif berkesinambungan dari suatu generasi ke generasi selanjutnya, sampai hari kiamat. Kemudian keduanya melanjutkan doanya: "Dan tunjukkanlah kepada kami cara-cara beribadah, yaitu terangkanlah ya Allah apa yang Engkau kehendaki lagi dari kami. Terangkan kepada kami bagaimana cara menyembah-Mu, bagaimana kami mendekatkan diri kepada-Mu. Di mana manasik mempunyai arti segala sesuatu yang dikehendaki Allah swt dari peribatan kepada-

\footnotetext{
${ }^{24}$ Muhammad Mutawalli asy-Sya'rawi, Tafsîr asy-Sya'rawi, cet. 1, jilid. 1, hal. 585-586.

${ }^{25}$ Muhammad Mutawalli asy-Sya'rawi, Tafsîr asy-Sya 'rawi, jilid. 1, hal. 587.
} 
Nya. Dan tunjukkan kepada kami cara-cara beribadah. Menerangkan bahwa pintu taklif akan dibukakan kepada Nabi Ibrâhîm as, karena dia memandang dalam taklif itu adalah pensucian diri dan kebaikan bagi anak cucunya, serta sebuah kenikmatan di akhirat kelak, karena itu Nabi Ibrâhîm as dan Nabi Ismâ'îl as melanjutkan doanya: "Dan terimalah taubat kami. Sesunguhnya Engkau yang Menerima taubat lagi Maha Penyayang. Bunyi watub 'alainâ - dan terimalah taubat kami, tidaklah harus bermakna taubat dari perbuatan maksiat. Mereka mengetahui bahwa generasi yang akan datang setelah mereka akan terjatuh dalam kemaksiatan, maka mereka memohon taubat untuk anak cucunya. Timbul pertanyaan "dari mana mereka mengetahuinya?" Jawabnya; dan kepada yang kafir pun Aku beri kesenangan sementara, kemudian akan Aku paksa ia menjalani siksa neraka dan itulah seburuk-buruk tempat kembali. $^{26}$

Ibadah mahdhah (murni) secara umum, dan ibadah haji secara khusus, adalah aktivitas pendekatan diri kepada Allah swt, yang ditentukan langsung waktu, kadar, dan caranya oleh Allah swt, dan disampaikan oleh Rasul-Nya. tidak ada peranan akal dalam hal ibadah itu, kecuali mencari hikmahnya. Kalau hikmah itu ditemukan, kita bersyukur. Kalau tidak, ia tetap harus dilaksanakan sesuai petunjuk yang diterima itu. Nabi Ibâhîm as memohon agar ditunjukkan cara-cara dan tempat ibadah haji, serta ibadah-ibadah lainnya, dan Allah swt mengabulkan doa beliau. ${ }^{27}$ Sehingga sampai saat ini, pelaksanaan ibadah haji berjalan dengan baik adalah jasa besar doa Nabi Ibâhîm as yang dipanjatkan kepada Allah swt. Kemudian dengan izin Allah swt, maka diwahyukan secara sempurna apa yang dilakukan Nabi Ibâhîm as kepada Nabi Muhammad saw.

Allah swt menyukai taubat dari hamba-Nya yang telah berbuat maksiat. Karena sifat maksiat menggiring manusia dengan memberikan kelezatan sesaat, maka kelezatan iman juga akan membawanya kembali kepada keimanan yang jauh dari maksiat. Oleh karena itu disebutkan, jika anda telah terjatuh pada kemaksiatan dan menyesali perbuatan tersebut, anda bukan hanya diampuni-Nya saja, tetapi kejahatan-kejahatan akan digantikan-Nya dengan kebaikan. Perintah taubat merupakan upaya pencegahan di tengah masyarakat dari kejahatan yang lebih besar lagi. Karena kalau seandainya tidak ada pengampunan dosa, niscaya kejahatan malah akan bertambah, dan masyarakat akan menderita akibat kejahatan yang berkepanjangan itu. Di sisi lain Nabi Muhammad saw pernah menyatakan dalam hadisnya: kullu bani Ada khathâun wa khaira khatthâîna at-Tawwâbûn - setiap anak Ădam berbuat kesalahan, dan

\footnotetext{
${ }^{26}$ Muhammad Mutawalli asy-Sya'rawi, Tafsir asy-Sya'rawi, jilid. 1, hal. 588.

${ }^{27}$ Muhammad Quraish Shihab, Tafsîr al-Mishbah, hal. 309.
} 
sebaik-baik orang yang bersalah adalah orang-orang yang bertaubat. (HR. Turmudzi). Oleh sebab itu, pensyariatan taubat sebenarnya adalah merupakan sebuah rahmat besar untuk menghindarkan kita dari kejahatan dan kemaksiatan. ${ }^{28}$

Nabi Ibrâhîm as berdoa agar diberikan kesempurnaan iman kepada anak cucunya dengan mengutus kepada mereka rasul yang menyampaikan risalah langit agar tidak terjadi periode kegelapan di bumi dan merajalelanya kerusakan, maksiat dan kekafiran, sebagaimana yang terjadi sebelum Nabi Ibrâhîm as yaitu: "Ya Tuhan kami, utuslah untuk mereka seorang rasul dikalangan mereka, yang membacakan kepada mereka ayat-ayat Engkau (ayat-ayat AlQur'ân ) dan mengajarkan kepada mereka Al-Kitâb (Al-Qur'ân ) dan al-Hikmah (as-Sunnah), serta menyucikan mereka, membersihkan mereka serta membawa mereka kepada jalan kebaikan dan kesempurnaan iman. Sesungguhnya Engkaulah Yang Maha Perkasa yang tidak dapat dikalahkan lagi Maha Bijaksana, tidak ada yang dapat keluar darinya kecuali kebijaksaan yang sempurna. ${ }^{29}$

Perbuatan Nabi Ibrâhîm as dan Nabi Ismâ'îl as ini, menjadi bimbingan kepada anak cucu mereka, sekaligus merupakan permohonan agar diberi keteguhan di atas ketaatan, bukan berarti bahwa mereka punya dosa, sebab para nabi maksum (terpelihara dari dosa). Dengan perbuatan tersebut mereka juga ingin menjelaskan kepada umat manusia-setelah mengetahui tata cara ibadah haji dau usai membangun Ka'bah-bahwa tempat-tempat tersebut adalah tempat untuk bersuci dan memohon tobat. Kemudian Nabi Ibrâhîm as melanjutkan doanya: "Wahai Tuhan kami, utuslah kepada umat Islam seorang rasul dari kalangan mereka agar ia lebih berbelas kasihan kepada mereka, agar mereka menjadi orang-orang yang sangat dimuliakan olehnya, dan supaya mereka lebih mudah untuk menerima dakwahnya, sebab mereka telah mengenal dengan seutuhnya, dan telah melihat kejujuran, amanah, ifah, istiqamah, dan sifatsifat sejenis pada dirinya. Ia membacakan kepada mereka ayat-ayat agama-Mu yang berisi pembuktian tentang keesaan Allah swt, serta tentang kebangkitan dan ganjaran, mengajari mereka Al-Qur'ân dan rahasia-rahasia serta tujuan-tujuan syariat, juga mengajari mereka ilmu pengetahuan yang menyempurnakan jiwa mereka, menyucikan mereka dari kotoran kesyirikan, keberhalaan, dan berbagai maksiat, dan mengajari mereka akhlak yang baik. Sesungguhnya Engkaulah Mahakuat Yang tak terkalahkan, Yang Maha Bijaksana dalam segala perbuatan-Engkau tidak melakukan kecuali yang sesuai dengan tuntunan hikmah

\footnotetext{
${ }^{28}$ Muhammad Mutawalli asy-Sya'rawi, Tafsîr asy-Sya'rawi, jilid. 1, hal. 588.

${ }^{29}$ Muhammad Mutawalli asy-Sya'rawi, Tafsîr asy-Sya'rawi, jilid. 1, hal. 589-590.
} 
Syarah Busyra, Lutfiah Sani

(kebijaksanaan) adalah pengetahuan tentang agama, pengertian tentang takwil, dan pemahaman yang merupakan tabiat (pembawaan) dan cahaya dari Allah swt. ${ }^{30}$

Doa-doa ini mengajarkan kepada manusia agar pada usai mengerjakan amal apapun memohon supaya amal-amal itu diterima oleh Allah swt, berdoa agar diri kita dan anak cucu kita diberi kesalehan supaya Islam tetap lestari sepanjang masa dan agar terlihat ketundukan kepada Sang Pencipta langit dan bumi. Allah swt menjadikan manasik haji sebagai tempattempat untuk membebaskan diri dari dosa dan untuk memohon rahmat dari Allah swt Dia Maha Pemurah lagi Maha Penyayang. Dia telah mengabulkan doa Nabi Ibrâhîm as dan putranya, Nabi Ismâ'îl as , dengan mengutus penutup para nabi, yaitu Nabi Muhammad saw sebagai rasul dari bangsa Arab.

Dalam referensi lain diberikan penjelasan, sebagai berikut: "Selanjutnya Nabi Ibrâhîm as meneruskan permohonannya: "Tuhan kami, jadikanlah kami, dua orang yang tetap dan bertambah tunduk patuh kepada-Mu dan jadikanlah juga anak cucu kami, ummat yang tunduk patuh kepada-Mu, dan tunjukkanlah kepada kami cara-cara dan tempat ibadah haji kami, terimalah taubat kami atau ilhami jiwa kami dengan kesadaran akan kesalahan kami. Sesungguhnya Engkaulah Yang Maha Penerima taubat lagi Maha Penyayang. Tuhan kami! Utuslah untuk mereka seorang rasul dari kalangan mereka yang terus membacakan kepada mereka ayat-ayat-Mu (baik yang berupa wahyu yang Engkau turunkan, maupun alam raya yang Engkau ciptakan), dan terus mengajarkan kepada mereka kandungan Al-Kitâb/Al-Qur'ân atau tulis baca, dan Al-Hikmah atau as-Sunnah atau kebijakan dan kemahiran melaksanakan hal yang mendatangkan manfaat serta menampik mudarat, serta mensucikan jiwa mereka dari segala macam kekotoran, kemunafikan, dan penyakit-penyakit jiwa. Sesungguhnya Engkau yang Maha Perkasa lagi Maha Bijaksana."31

Demi setelah selesai Nabi Ibrâhîm as dibantu oleh putranya Nabi Ismâ'îl as mendirikan rumah itu, merekapun bermunajat kepada Tuhan: "Ya Tuhan kami, terimalah dari pada kami, pekerjaan yang Engkau perintahkan kepada kami berdua, ayah dan anak, mendirikan Ka'bah sudah selesai. Sudilah kiranya menerima pekerjaan itu: "Sesungguhnya Engkau adalah Maha Mendengar akan segala permohonan kami dan doa kami, Engkau Maha Mengetahui jika terdapat kekurangan di dalam pekerjaan kami ini, Engkaulah yang lebih tahu." 32

\footnotetext{
${ }^{30}$ Wahbah Mushthafâ az-Zuhaili, At-Tafsîr al-Munîr, jilid. 1, hal. 340.

${ }^{31}$ Muhammad Quraish Shihab, Tafsîr al-Mishbah, hal. 309-310.

${ }^{32}$ Hamka, Tafsîr al-Azhar, (Jakarta: Yayasan Nurul Islam, 1981), cet. 3, juzu' 1, hal. 402.
} 
Setelah dengan segenap kerendahan hati, kedua makhluk bapak dan anak itu, Nabi Ibrâhîm as dan Nabi Ismâ'îl as , yang telah menjadi manusia terpilih di sisi Tuhan, memohonkan supaya amalan mereka diterima oleh Tuhan, mereka teruskan munajat itu. Si ayah yang berdoa dan si anak yang mengaminkan: "Ya Tuhan kami! Jadikanlah kami keduanya ini orang-orang yang berserah diri kepada Engkau, keduanya berjanji bahwa rumah yang suci itu hanyalah untuk beribadah dari pada orang-orang yang berserah diri kepada Allah swt, tidak bercampur dengan penyerahan diri kepada yang lain. Kemudian Nabi Ibrâhîm as meneruskan doanya: "dan dari keturunan-keturunan kamipun (hendaknya) menjadi orang-orang yang berserah diri kepada Engkau. Bukan saja Nabi Ibrâhîm as mengharapkan penyerahan dirinya dan putranya Nabi Ismâ'îl as kepada Allah swt, agar diterima Allah swt. Bahkan beliaupun memohonkan kepada Allah swt agar anak cucu keturunannya yang datang di belakangpun menjadi orang-orang yang berserah diri, menjadi orang-orang yang muslim atau islam, sehingga cocoklah dan sesuailah hendaknya langkah dan sikap hidup anak cucu keturunannya dengan dasar pertama ketika rumah itu didirikan: "Dan tunjukkan kiranya kepada kami caracara kami beribadat. Dan berilah taubat atas kami, sesungguhnya Engkau adalah penerima taubah lagi penyayang." 33

Nabi Ibrâhîm as memohonkan taubat untuk dirinya dan untuk anaknya ini adalah suatu teladan bagi kita agar selalu ingat dan memohonkan ampun kepada Tuhan. Kemudian Nabi Ibrâhîm as melanjutkan doanya: "Ya Tuhan kami! Bangkitkanlah di antara mereka itu seorang rasul dari mereka sendiri, yang akan membacakan kepada mereka ayat-ayat Engkau, yaitu perintah-perintah Ilâhi untuk memupuk dasar yang telah beliau tinggalkan di dalam mengakui ke-Esaan Tuhan. Dan menganjurkan kepada mereka kitab (kumpulan dari pada wahyu-wahyu yang diturunkan Ilâhi/Al-Qur'ân ) dan hikmat (kebijaksanaan di dalam cara menjalankan perintah, baik di dalam perkataan atau perbuatan atau sikap hidup Nabi itu sendiri, yang akan diajadikan contoh dan tauladan bagi umatnya), dan yang membersihkan mereka (bersih dari pada kepercayaan yang karut-marut, syirik dan menyembah berhala, dan bersih pula kehidupan sehari-hari dari pada rasa benci, dengki, bohong, dan khianat). Sesunggunya Engkau adalah Maha Gagah, lagi Maha Bijaksana."34

Dalam literatur lain diberikan penjelasan mengenai firman Allah swt pada sûrah AlBaqarah/2 ayat 127-129 adalah sebagai berikut, "Jadikanlah kami dua orang yang patuh kepada perintah-Mu, tunduk dalam ketaatan kepada-Mu, dan dalam pelaksanakan ketaatan dan ibadah

\footnotetext{
${ }^{33}$ Hamka, Tafsîr al-Azhar, juzu' 1, hal. 403.

${ }^{34}$ Hamka, Tafsîr al-Azhar, juzu' 1, hal. 405-407.
} 
itu tidak menyekutukan-Mu dengan seorang pun selain-Mu. Dan jadikanlah sebagian keturunanku sebagai umat yang berserah diri kepada-Mu. Dan tunjukkanlah kepada kami tata cara berhaji (tampilkan dan ajarkanlah kepada kami). Kemudian untuk menyempurnakan dakwahnya kepada penduduk Tanah Harâm, Nabi Ibrâhîm as memohon kiranya Allah swt mengutus kepada mereka seorang rasul dari kalangan mereka sendiri. Allah swt menetapkan permintaan tersebut dengan menentukan Nabi Muhammad saw sebagai rasul bagi kaum yang ummi (bangsa Arab) dan bagi seluruh golongan jin dan manusia." ${ }^{\prime 35}$

Pada ayat 127 surah Al-Baqarah prinsip dasar pendidikan rabbaniyyah adalah beramal penuh dengan keikhlasan.

Pada ayat 128 surah Al-Baqarah prinsip dasar pendidikan rabbaniyyah adalah memohon dijadikan orang yang tunduk, patuh, taat kepada Allah SWT.

Pada ayat 129 surah Al-Baqarah prinsip dasar pendidikan raabbaniyyah adalah mempersiapkan generasi yatluuna Kitaballah, sesuai dengan doa Nabi Ibrahim AS surah AlBaqarah/2 ayat 129 ,

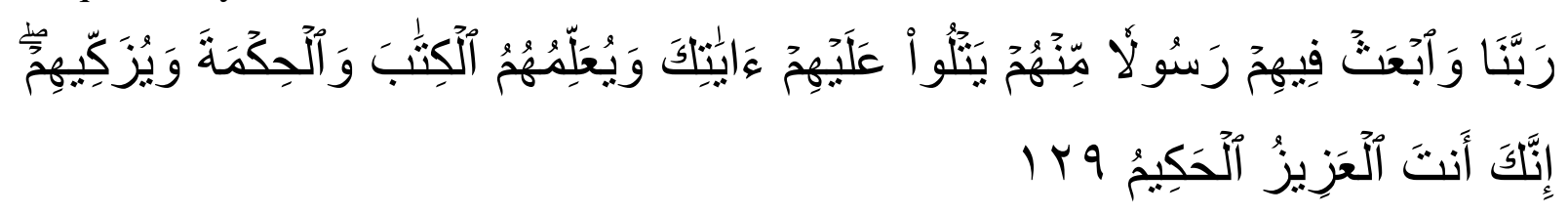

Ya Tuhan kami, utuslah untuk mereka sesorang Rasul dari kalangan mereka, yang akan membacakan kepada mereka ayat-ayat Engkau, dan mengajarkan kepada mereka Al-Kitab (AlQur'an) dan Al-Hikmah (As-Sunnah) serta mensucikan mereka. Sesungguhnya Engkaulah yang Maha Kuasa lagi Maha Bijaksana.

Kemudian prinsip dasar utama adalah revolusi membaca, khususnya membaca kitab suci AlQur'an, yang merupakan sumber pengetahuan utama yang mengandung prinsip-prinsip dasar pendidikan. Secara khusus yang diilhami wahyu pertama yang diturunkan kepada baginda Nabi Muhammad SAW, yakni:

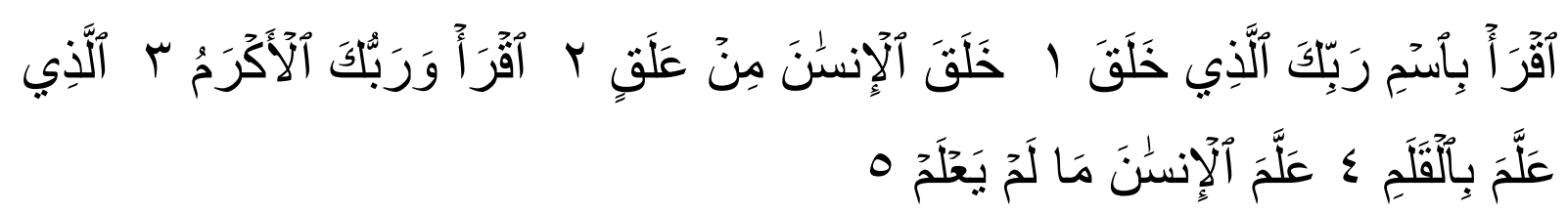

Bacalah dengan (menyebut) nama Tuhanmu Yang menciptakan. Dia telah menciptakan manusia dari segumpal darah. Bacalah, dan Tuhanmulah Yang Maha Pemurah. Yang mengajar (manusia) dengan perantaran kalam. Dia mengajar kepada manusia apa yang tidak diketahuinya. (Q. S. Al-Alaq/96: 1 - 5).

\footnotetext{
${ }^{35}$ Muhammad Nasib ar-Rafa'i, Kemudahan dari Allah Ringkasan Tafsir Ibnu Katsir, penerjemah: Syihabuddin, jilid 1, hal. 230.
} 
Serta puncak membaca adalah yatluuna kitaballah, yaitu penyatuan prinsip dasar membaca AlQur'an secara baik dan benar, memahami kandungan Al-Qur'an dan berupaya melaksanakan pesan-pesan kandungan Al-Qur'an dalam kehidupan, sebagaimana direkam dalam firman Allah SWT pada surah Faathir/35 ayat 29,

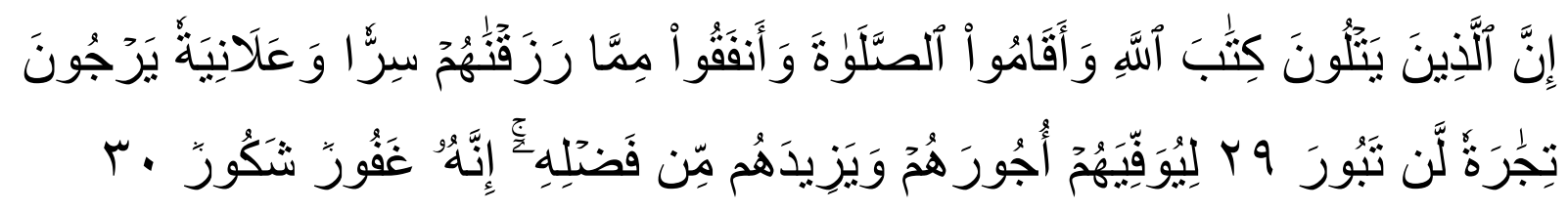

Sesungguhnya orang-orang yang selalu membaca kitab Allah dan mendirikan shalat dan menafkahkan sebahagian dari rezeki yang Kami anugerahkan kepada mereka dengan diamdiam dan terang-terangan, mereka itu mengharapkan perniagaan yang tidak akan merugi, agar Allah menyempurnakan kepada mereka pahala mereka dan menambah kepada mereka dari karunia-Nya. Sesungguhnya Allah Maha Pengampun lagi Maha Mensyukuri. (Q. S. Fathur/35: $29-30)$.

\section{Upaya upaya mengoptimalkan pendidikan rabbaniyyah}

Salah satu cara untuk mengoptimalkan pendidikan rabbaniyyah adalah melakukan tafakur dan taddabur terhadap cintaan Allah SWT yang terhampar luas di jagad raya, langit dan bumi, sebagaimana dijelaskan beberapa ayat berikut:

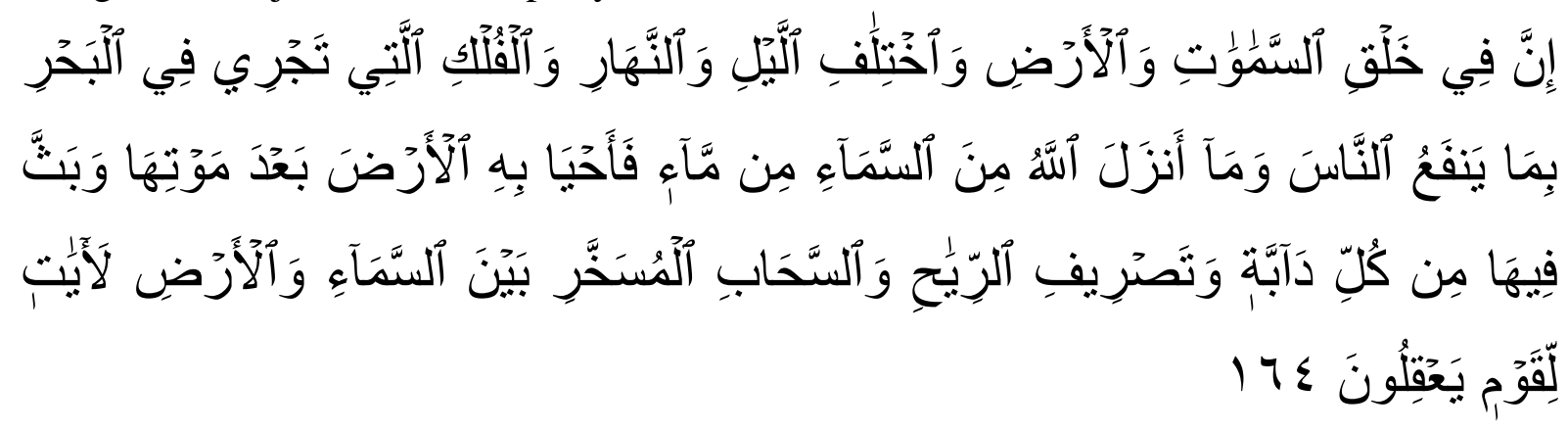

Sesungguhnya dalam penciptaan langit dan bumi, silih bergantinya malam dan siang, bahtera yang berlayar di laut membawa apa yang berguna bagi manusia, dan apa yang Allah turunkan dari langit berupa air, lalu dengan air itu Dia hidupkan bumi sesudah mati (kering)-nya dan Dia sebarkan di bumi itu segala jenis hewan, dan pengisaran angin dan awan yang dikendalikan antara langit dan bumi; sungguh (terdapat) tanda-tanda (keesaan dan kebesaran Allah) bagi kaum yang memikirkan. (Q. S. Al-Baqarah/2: 164).

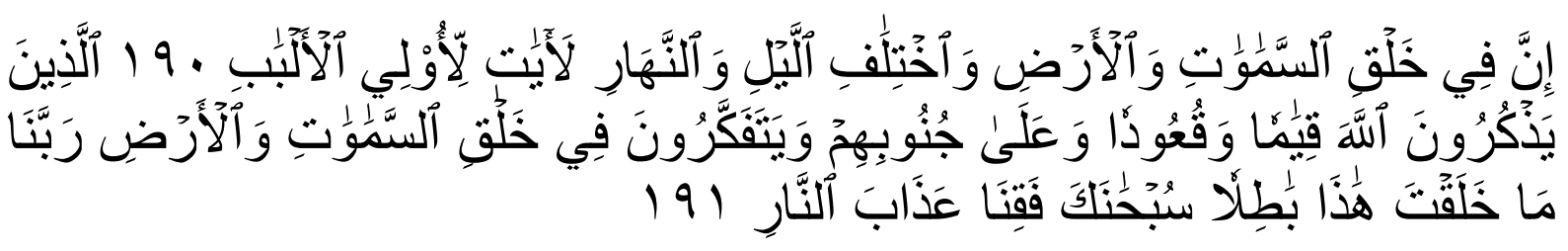

Sesungguhnya dalam penciptaan langit dan bumi, dan silih bergantinya malam dan siang terdapat tanda-tanda bagi orang-orang yang berakal. (yaitu) orang-orang yang mengingat Allah sambil berdiri atau duduk atau dalam keadan berbaring dan mereka memikirkan tentang penciptaan langit dan bumi (seraya berkata): "Ya Tuhan kami, tiadalah Engkau menciptakan 
ini dengan sia-sia, Maha Suci Engkau, maka peliharalah kami dari siksa neraka.(Q S. Ali Imran/3: $190-191)$.

\section{Menghidupkan kembali nilai-nilai Al-Qur'an dalam kehidupan}

Untuk menghidupkan kembali nilai-nilai Al-Qur'an dalam kehidupan, maka salah satu upayanya adalah memahami kembali secara utuh peran manusia dalam kehidupan, di mana manusia sebagai an-Nas (makhluk sosial) harus benar-benar dipahami dengan baik. Berikut ini pemaparan khusus tentang manusia sebagai an-Nas (makhluk sosial) sebagai bahan acuan agar pendidikan rabbaniyyah dapat terwujud dengan baik dalam kehidupan bermasyarakat, berbangsa dan bernegara.

Kata an-Nâs dalam Al-Qur'ân termasuk yang paling banyak digunakan, aitu terulang sebanyak 241 kali. Menurut Ar-Raghib al-Isfahani, ketika kata an-Nâs disebutkan dalam AlQur'ân, maka yang dimaksud adalah manusia dengan segala kelebihan, keluhuran akhlak dan kepribadiannya. Hal ini misalnya terkandung dalam kata an-Nâs ketika digunakan dalam QS. An-Nâs/114: 1; QS. Al-Baqarah/2: 13; dan QS. An-Nisâ'/4: 54. ${ }^{36}$

Konsep an-Nâs selalu merujuk pada peran manusia dalam kehidupan sosial. Manusia diarahkan agar menjadi warga sosial, yang pada akhirnya diharapkan dapat memberikan manfaat bagi kehidupan bersama di masyarakat. Dengan demikian, konsep an-Nâs mengacu kepada peran dan tanggung jawab manusia sebagai makhluk sosial dalam statusnya sebagai makhluk ciptaan Allah swt. ${ }^{37}$

Pendapat lain memeberikan informasi, bahwa kata an-Nâs berasal dari kata unas yang dibuang alif-nya ketika memakai alif-lam (dari al-Unâs jadi an-Nâs). Ada juga yang mengatakan berasal dari kata nasiya-insiyyan yang berarti lupa. ${ }^{38}$ Atau dari kata nawasa atau nasa-yanusu yang dalam bahasa Arab mengandung makna goncang atau fluktuatif. Karenanya sebagai makhluk sosial, setiap kali manusia bertemu dengan sesamanya, maka dapat menyebabkan kegoncangan dan fluktuasi dalam kehidupan sosial, politik dan ekonomi. Artinya, kehidupan manusia tidak berjalan dengan formula yang teratur atau konsisten, sebagaimana dengan makhluk-makhluk lain seperti lebah (an-Nahl), semut (an-Naml), labalaba (al-Ankabût) atau lainnya. Manusia mengalami kegoncangan dan fluktuasi dalam

\footnotetext{
${ }^{36}$ Ar-Raghib al-Isfahani, Mufradât Gharîb Al-Qur'ân, (Mesir: Al-Halabi, 1961), hal. 531.

37 Jalaluddin, Teologi Pnedidikan, (Jakarta: PT. RajaGrafindo Persada, 2003), hal. 25.

${ }^{38}$ Al-Raghib al-Isfahani, Mufradât Gharîb Al-Qur'ân, hal. 531.
} 
pengertian bahwa mereka dapat berpindah dari satu tempat ke tempat lainnya secara sadar. Setiap kali kemajuan manusia bertambah, maka saat itu juga bertambah sisi kemanusiannya. ${ }^{39}$

Dalam Al-Qur'ân kata an-Nâs sebenarnya lebih banyak menunjuk kepada manusia sebagai makhluk sosial atau dalam pengertian sosiologis sebagaimana terlihat dalam pengertian kebahasaan. Bahkan dalam mengungkap manusia sebagai makhluk sosial, AlQur'ân tidak pernah melakukan generalisasi. ${ }^{40}$ Namun perlu dipahami, bahwa dengan merujuk kepada sumber Al-Qur'ân, manusia sebagai makhluk sosial secara universal mempunyai pesan-pesan khusus, di mana manusia diarahkan dan dituntun agar dapat menjalani kehidupan di dunia ini dengan penuh kebersamaan. Kebersamaan dalam hal ibadah diarahkan agar semua manusia hanya menyembah kepada Allah swt (Q.S. Al-Baqarah/2: 21), dan juga dalam hal mencari karunia berupa sandang, pangan, dan papan (Q.S. Al-Baqarah/2: 168-170).

Berikut beberapa ayat Al-Qur'ân yang mengandung kata an-Nâs, yang merupakan bagian penting untuk diketahui dan dipahami, bahwa kata tersebut merujuk kepada kehidupan sosial manusia, namun tentunya dibalik itu ada pesan khusus yang disampaikan Al-Qur’ân, di mana penulis pada bagian ini menukil sebagian ayat-ayat Al-Qur'ân yang diawali dengan kata "Yâ ayyuha an-Nâs". Di antaranya adalah:

Sûrat Al-Baqarah/2: 21,

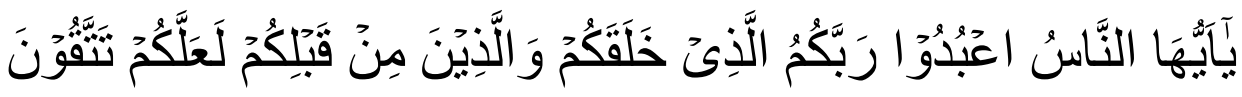

Hai manusia, sembahlah Tuhanmu yang telah menciptakanmu dan orang-orang yang sebelummu, agar kamu bertakwa.

Wahbah Mushthafâ az-Zuhaili memberikan penafsiran terhadap ayat di atas, sebagai berikut: "Kaum mukminin memiliki keistimewaan berupa akal, mata hati, kesetiaan, dan pengakuan akan kebenaran dan keindahan. Di dalam peribadahan kaum muslimin kepada Allah swt semata terwujud penghambaan kepada Allah swt yang dituntut dari mereka, kecintaan dan ketakwaan kepada-Nya, sikap istiqamah di atas manhaj yang shahih, serta rasa syukur kepada Allah swt yang menjadikan bumi layak ditempati, padahal ia selalu bergerak dan berputar, yang menjadikan langit laksana kubah yang menaungi mereka dengan kebaikan dan keberkahan. Langit ibarat bangunan yang kokoh, betapa pun di dalamnya terdapat jutaan bintang dan planet, tata surya dan galaksi, tidak ada satu pun yang jatuh, tidak ada sistem pun yang rusak. Allah swt sebagai pencipta itu semua, sebagaia pemberi nikmat dan kerunia, Dia semata yang berhak

\footnotetext{
284.

${ }^{39}$ Muhammad Syahrur, Al-Kitâb wa Al-Qur'ân: Qiraat al-Mu'ashirat, (Damaskus: Al-Ahali, 1990), h.

${ }^{40}$ Jalaluddin Rahmat, Islam Alternatif, (Bandung: Mizan, 1991), hal. 79-80.
} 
atas peribadahan, ketundukan dan kepatuhan, sebab Dia-lah sumber penciptaan, pembentukan, dan rezeki. ${ }^{41}$ Sedangkan menurut M Quraish Shihab ayat di atas mengandung penafsiran: "Wahai seluruh manusia yang mendengar panggilan ini beribadahlah, yaitu tunduk, patuh dengan penuh hormat, dan kagumlah kepada Tuhan kamu Sang Pemelihara dan Pembimbing, karena Dialah yang menciptakan kamu dan yang sebelum kamu."42 Lebih lanjut beliau merinci, "Ibadah adalah suatu bentuk kepatuhan dan ketundukan yang berpuncak kepada sesuatu yang diyakini menguasai jiwa raga seseorang dengan penguasaan yang arti dan hakikatnya tidak terjangkau. Karena itu, ketundukan dan kepatuhan kepada orang tua atau penguasa tidak wajar dinamai ibadah."43

Sementara Hamka memberikan penafsiran ayat di atas, sebagai berikut: "Wahai manusia - rata seruan kepada seluruh manusia yang telah dapat berfikir, "Sembahlah olehmu akan Tuhanmu yang telah menciptakan kamu. Dari tidak ada, kamu telah diadakan dan hidup di atas bumi, dan orang-orang sebelum kamu, datang ke dunia mendapat sawah dan ladang, rumah tangga dan pusaka yang lain dari nenek moyang sehingga yang datang kemudian hanya melanjutkan apa yang dicencang dan dilatih oleh orang tua-tua. Maka orang tua-tua yang telah meninggalkan pusaka itupun Allah jualah yang menciptakan mereka. Disuruh mengingat itu, supaya kamu terpelihara dan memelihara diri dan kemanusiaan, jangan jatuh martabat jadi binatang, dengan jalan beribadat, berbakti dan menyembah Allah swt, mensyukuri nikmat yang telah dilimpahkannya." 44

Dari pendapat di atas didapat informasi bahwa manusia sebagai an-Nâs diperintahkan oleh Allah swt agar hanya menyembah/beribadah kepada Allah semata, tidak menyembah kepada selain-Nya. Pada ayat tersebut, Allah swt menegaskan bahwa Allah swt adalah Dzat yang telah menciptakan manusia, baik manusia yang hidup pada zaman Rasulullah saw, pada masa yang lampau, juga masa sekarang. Diharapkan agar manusia semuanya hanya menyembah Allah s.w.t, juga perintah tersebut diharapkan pula agar manusia menjadi orangorang yang bertaqwa kepada Allah swt.

Sûrat An-Nisâ'/4: 174,

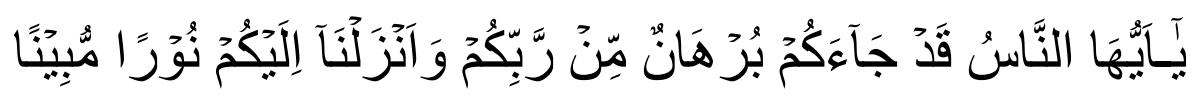

${ }^{41}$ Wahbah Muahthafâ az-Zuhaili, At-Tafsîr al-Wasîth, Jilid.1, hal.

${ }^{42}$ M Quraish Shihab, Tafsîr Al-Mishbâh, Volume. 1, hal. 117.

${ }^{43}$ M Quraish Shihab, Tafsîr Al-Mishbâh, Volume. 1, hal. 117.

${ }^{44}$ Hamka, Tafsir Al-Azhar, juzu'. I, hal. 187. 
Hai manusia, sesungguhnya telah datang kepadamu bukti kebenaran dari Tuhanmu. (Muhammad dengan mukjizatnya) dan telah Kami turunkan kepadamu cahaya yang terang benderang (Al-Qur'ân).

Wahbah Mushthafâ az-Zuhaili memberikan penafsiran terhadap ayat di atas, sebagai berikut: "Allah swt menjelaskan jalan keselamatan kepada seluruh manusia. Allah swt memberitahukasn mereka bahwa Ia telah mendatangkan bukti dan hujjah yang terang benderang yang memberikan keyakinan secara sempurna, menjelaskan hakikat keimanan kepada Allah swt, bukti nyata itu adalah Nabi Muhammad saw, nabi dari bangsa Arab yang buta huruf, tidak belajar di sekolah maupun universitas. Namun, Allah swt memberinya kesiapan khusus untuk menyampaikan risalah paling agung di jagat raya untuk seluruh manusia." 45 Lebih lanjut beliau memberikan penafsiran, "Nabi Muhammad saw telah datang kepada kalian wahai seluruh manusia dengan membawa bukti yang nyata dari Allah swt atas kebenaran dakwah yang disampaikan kepada kalian dan rusaknya agama dan sekte-sekte paganis kalian. Itulah bukti nyata Ilahi atas kebenaran dakwahnya; Al-Qur'ân Al-Karîm atau Nabi Muhammad saw sendiri. Al-Qur'ân adalah cahaya yang nyata, di dalamnya terdapat penjelasan segala sesuatu. Al-Qur'ân adalah petuah yang mencegah, melarang, dan memerintah." 46

Hamka memberikan penafsiran sebagai berikut: "Wahai sekalian manusia - tidak memandang kabilah atau keturunan dan tidak bangsa atau pun warna kulit, sebab perasaan batin mereka adalah sama. Sesungguhnya telah datang kepadamu keterangan dari Tuhan kamu. Allah Yang Maha Pengasih dan Penyayang, dengan karunia dan 'inayah-Nya, guna mendidik dan membersihkan jiwa kamu telah mendatangkan dari sisi-Nya, untuk burhan, yaitu keterangan yang besar, yang jelas dan nyata. Membawa hakikat iman yang besar kepada Allah swt, supaya hidupmu selamat, beragama dan berbudi, sentosa dunia dan akhirat. Burhan atau keterangan itu datang dengan cukup penjelasan dan keterangan, dengan dalil dan alas an. Burhan atau keterangan itu ialah seorang manusia, bernama Muhammad saw."47 Lebih lanjut Hamka menafsirkan, "Dan telah Kami turunkan kepada kamu cahaya yang nyata, yaitu wahyu yang Nabi Muhammad saw terima dari Tuhan dengan perantaraan malaikat Jibril as, yang bernama Al-Qur'ân, yang merupakan cahaya pada dirinya dan memberikan cahaya pada yang lain. Yang disinarinya ialah roh insani, sebab cahaya roh itu membekas pada jasmani. Bertambah dia dibaca dan difahamakan, bertambah membekaslah cahaya itu ke dalam jiwa. Al-Qur'ân menerangkan apa artinya hidup ini dank e mana lanjutan sesudah mati, dan bekal

\footnotetext{
${ }^{45}$ Wahbah Muahthafâ az-Zuhaili, At-Tafsîr al-Wasîth, Jilid.1, hal.420.

${ }^{46}$ Wahbah Muahthafâ az-Zuhaili, At-Tafsîr al-Wasîth, Jilid.1, hal. 420.

${ }^{47}$ Hamka, Tafsir Al-Azhar, juzu'. V1, hal. 90-91.
} 
Syarah Busyra, Lutfiah Sani

apa yang harus dibawa. Nur atau cahaya Al-Qur'ân memancar, mengingatkan tauhid dan merumuskanya, tersimpul dalam kalimat: Laa Ilha Illallah."

Dari beberapa penfasiran di atas, diberikan informasi kepada seluruh umat manusia, bahwa telah datang sebuah kebenaran dari Allah swt yaitu dengan diutusnya Nabi Muhammad saw sebagai nabi dan rasul terakhir, dan sekaligus dilengkapi dengan diturunkannya kitab Suci Al-Qur'ân sebagai pedoman hidup manusia dari zaman ke zaman sampai akhir zaman. Dalam konteks ini, Allah swt memberikan dalil/hujjah yang sangat kuat bagi manusia, bahwa dengan diutusnya Nabi Muhammad saw adalah untuk membuktikan kebenaran adanya Allah swt, tugas Rasulullah saw adalah mengajak seluruh umat manusia agar hanya beribadah kepada Allah swt, melalui tuntunan syari'at Islam, yaitu dengan melakukan shalat lima waktu sehari semalam, dan tuntunan syari'at lainnya. Setelah Rasulullah saw wafat, maka diteruskan menyampaikan ajaran Islam oleh para shahabat, demikian seterusnya sampai pada zaman sekarang ini, dan kitab Suci Al-Qur'ân tetap relevan sebagai pedoman hidup manusia. Dengan kata lain, Allah swt memerintahkan agar semua manusia hanya beribadah dan bertaqwa kepada-Nya (Q.S. Al-Baqarah/2: 21), kemudian untuk merealisasikan perintah tersebut Allah swt mengutus Nabi Muhammad saw dengan membawa syari'at Islam dan sekaligus menurunkan kitab Suci Al-Qur'ân sebagai pedoman hidup manusia (Q.S. An-Nisâ'/4: 174).

Sûrat Yûnus/10: 57,

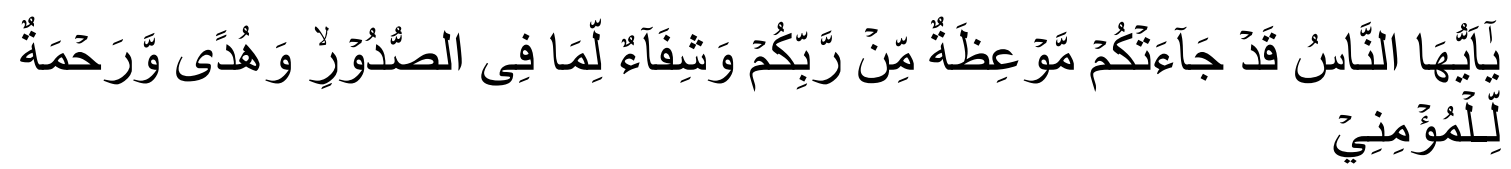

Hai manusia, sesungguhnya telah datang kepadamu pelajaran dari Tuhanmu dan penyembuh bagi penyakit-penyakit (yang berada) dalam dada dan petunjuk serta rahmat bagi orang-orang yang beriman.

Hamka memberikan penafsiran sebagai berikut: "Wahai manusia - seruan kepada seluruh manusia, supaya manusia tidak usah bingung memikirkan hari depannya. Tuhan menunjukkan atau menerangkan bahwa betapa pun sulitnya jalan yang akan ditempuh, akan dapatlah dia diatasi, sebab Tuhan telah memberikan pedoman (kitab Al-Qur'ân) yang mengandung empat unsur penting di dalam menempuh kehidupan, yaitu: Al-Qur'ân merupakan pengajaran atau tuntunan, baik dalam pembangunan akhlak atau karakter, sikap hidup, membedakan baik dan buruk, mengatur dengan baik hubungan Allah swt dan sesama manusia; suatu obat bagi apa yang ada dalam dada (hati sanubari/nurani), bahwasannya AlQur'ân merupakan obat bagi segala macam penyakit jiwa; Al-Qur'ân merupakan hudan atau

\footnotetext{
${ }^{48}$ Hamka, Tafsir Al-Azhar, juzu'. VI, hal. 92-93.
} 
petunjuk untuk menempuh semak belukar kehidupan ini, supaya manusia jangan tersesat; AlQur'ân merupakan rahmat, kurnia kasih dan sayang kepada orang-orang yang beriman." ${ }^{49}$

Dari keterangan Hamka di atas, memberikan rincian lebih luas lagi bahwa dengan diturunkanya kitab Suci Al-Qur’ân merupakan pelajaran yang sangat berharga bagi manusia, karena di dalam Al-Qur'ân terdapat syifa/penyembuh bagi berbagai penyakit ruhaniyah, juga tuntunannya merupakan petunjuk menuju jalan yang benar, serta menjadi rahmat bagi orangorang yang beriman. Dalam konteks ini, setiap an-Nas seharusnya semuanya mengacu kepada Al-Qur'ân Al-Karîm, karena begitu sangat jelas, bahwa Al-Qur'ân Al-Karîm merupakan mukjizat terbesar yang berlaku sepanjang zaman, yang mana di dalamnya terdapat syifa/penyembuh, petunjuk dan rahmat yang akan mengantarkan kepada kehidupan yang penuh bahagia di dunia dan akhirat kelak. Walaupun pada kenyataannya, kebanyakan manusia sebagai an-Nâs sudah jauh dari Al-Qur'ân dan tidak mau mengambil manfaatnya, hanya sebagian kecil manusia saat ini yang berpegang kepada Al-Qur'ân Al-Karîm yang merupakan bagian dari kehidupannya.

\section{Kesimpulan}

Untuk mencapai pendidikan rabbaniyyah yang sempurna, maka sebagai langkah awal adalah adanya upaya revolusi membaca kitab suci Al-Qur'an, kemudian berusaha memahami kandungannya secara berkala dan istiqamah, yang selanjutnya berusaha mengamalkan kandungan Al-Qur'an dalama kehidupan. Terurama memahami ayat-ayat yang berikatan dengan manusia sebagai an-Nas (makhluk sosial), sehingga akan terbentuk sebuah kehidupan yang aman, damai, tentram, dan penuh dengan kesejahteraan, karena menyadari betul bahwa hidup manusia perlu dibangun saling tolong menolong, bantu membantu dan saling menghirmati satu dengan yang lainnya. Itulah inti kehidupan dari pada pendidikan rabbaniyyah manusia.

${ }^{49}$ Hamka, Tafsir Al-Azhar, juzu'. XI, hal. 235. 
Syarah Busyra, Lutfiah Sani

\section{Daftar Pustaka}

Al-Qur'ân Al-Karîm

Al-Qur'ân Al-Karîm bi ar-Rasm al-Utsmâî, Al-Insân al- 'Alaqah al-Akhlaqiyah, Damsyiq: Dâr al-Ma'rufâh, cet. 4, $1420 \mathrm{H}$.

Abd al-Baqi, Muhammad Fuad, Al-Mufahras li Alfaz Al-Qur'ân Al-Karîm, Mesir: Dâr alHadits, 1422 H/ 2001 M.

Al-Ashfahani, Ar-Raghib, Mu'jam Mufradât Alfazh Al-Qur'ân, Beirut: Dâr al-Fikr, TT.

Al-Ishfahani, Abu al-Qasim Abu al-Husain bin Muhammad al-Ragib, Al-Mufradât fî Garîb AlQur'ân, Mesir: Mustafâ al-Bâb al-Halâbî, 1961.

Al-Jamal, Muhammad Abd al-Mun'im, At-Tafsîr al-Farîd Lil Qur'â Al-Majîd, Kairo: Research Publicaation Dept, cet. 1, 1952.

Al-Maghlouth, Sami bin Abdullah, Atlas Tarikh al-Anbiyâ' wa ar_rasul, edisi terjemah: Atlas Sejarah Para Nabi \& Rasul Menggali Nilai-nilai Kehidupan para Utusan Allah, penerjemah: Qasim Shaleh, dkk, Jakarta: Almahera, cet. 4, 2012.

............, Sami bin Abdullah, Atlas Tarikh li Sirah ar_rasul, edisi terjemah: Atlas Perjalanan Hidup Nabi Muhammad Napak Tilas Jejak Perjuangan dan Dakwah Rasulullah, penerjemah: Dewi Kournia Sari, dkk, Jakarta: Almahera, cet. 4, 2011.

Asy-Sya'râwî, Muhammad Mutawali, Tafsîr asy-Sya 'râwî̀, jilid. 1, 2, 12, 17, Kairo: Idarah alKutub wa al-Maktabat, $1411 \mathrm{H} / 1991 \mathrm{M}$.

Ath-Thabari, Abû Ja'far Muhammad bin Jarîr, Jâmi' al-Bayân fî Tafsîr Ayi Al-Qur'ân, jilid. 1, 4, 7, 8, 9, Beirut: Dâr al-Fikr , 1988.

Az-Zuhaili, Wahbah, At-Tafsir al-Munîr, jilid. 1, 2, 5, Beirut: Dâr al-Fikr, cet. II, 1426 H/2005 M.

At-Tafsîr al-Wasîth, jilid. 1, 2, 3, Beirut: Dâr al-Fikr al-Mu'hsir, cet. 1, 2001.

Dirks, Jeradl F, Ibrâhîm Sang Sahabat Tuhan, penerjemah: Satrio Wahono, Jakarta: PT Serambi Ilmu Semesta, cet. 2, 2006.

Faqih, Kamal dan Tim Ulama, Tafsîr Nûrul Qur'ân, penerjemah: R Hikmat Danaatmaja, Jakarta: Penerbit al-Huda, cet. 1, 2003.

Firdaus, Slamet, Konsep Manusia Ideal Dalam Al-Qur'ân (Studi Profil al-Musin dalam Perspektif Tafsîr Ayat-ayat Ihsan), Tangerang: Makmur Abadi Press, cet. 1, 2011.

Hamka, Tasauf Moderen, Jakarta: Pustaka Panjimas, 2000. ., Tafsîr al-Azhar, jilid. 1, 3, 5, 6, 9, 11, 12, 17, 23, Jakarta: Panji Masyarakat, TT.

Hanafi, Muchlis Muhammad dkk, Tafsîr Al-Qur'ân Tematik, Al-Qur'ân dan Kenegaraan, Jakarta: Lajnah Pentashihan Mushhaf Al-Qur'ân, cet. 1, 2012.

......, Tafsîr Al-Qur'ân Tematik, Kenabian (Nubuwwah) dalam Al-Qur'ân, Jakarta: Lajnah Pentashihan Mushhaf Al-Qur'an, cet. 1, 2012.

......., Al-Qur'ân dan Kenegaraan, Jakarta: Lajnah Pentashihan Mushhaf Al-Qur'an, cet. 1, 2012.

Hude, M Darwis, Emosi Penjelajahan Religio-Psikologis tentang Emosi Manusia di dalam AlQur'ân, Jakarta: Erlangga, cet. 1, 2006.

Logika Al-Qur'ân Pemaknaan Ayat Dalam Berbagai Tema, Jakarta: PT Nagakusuma Media Kreatif, cet. 1, 201.

Shihab, Muhammad Quraish, Tafsîr al-Mishbâh, jilid. 1-15, Jakarta: Lentera Hati, cet. I, 2000. Tafsir Al-Qur'ân Al-Karîm Tafsîr atas Surat-surat Pendek Berdasarkan Urutan Turunnya Wahyu, Bandung: Pustaka Hidayah, cet. II, 1997.

Surasman, Otong, Bercermin Pada Nabi Ibrahim As, Jakarta, Gema Insani Press, 2016. 